\title{
Implementing Curricula To Meet The Needs Of Financial Professionals
}

G. Richard French, (E-mail: gfrench@ius.edu), Indiana University Southeast

Richard E. Coppage, (E-mail: coppage@louisville.edu), University of Louisville

\begin{abstract}
Major changes in the financial profession warrant assessment of current practices and strategic planning for the future education of such professionals. This article discusses the core competencies, obtained from numerous studies, of accounting and finance professionals. After common core competencies are identified for the both accounting and finance professions, the need for change in accounting and finance curricula are discussed. Next, a combined undergraduate curriculum for both the accounting and finance students, which incorporates the common core competencies, is proposed. Finally, the authors issue a call for further research.
\end{abstract}

\section{Introduction}

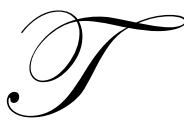

here are significant changes in the financial profession influenced by a variety of pressures. These pressures include: 1) globalization of the business environment, 2) technological advances that require systems-oriented analysis and reduce the need for task-oriented activities in the finance function, 3) a lack of confidence of the investing public in the ethics of financial professionals (both corporate finance officers and their public accountants), 4) the adequacy of financial reporting of financial transactions of business entities to investors and other external/internal parties, 5) different economic times where cost cutting is critical to the survival of the firm, 6) identification of financial tools that adequately assess the value of the firm and the contribution of activities increasing this value, and 7) a need to understand integrated business activities. It is critical to consider the rapidly changing business environment in the development of curricula to educate financial professionals in our academic programs. For purposes of this paper, we will define financial professionals in broad terms consistent with the business environment and marketplace that our students encounter upon graduation.

Financial professionals are those individuals that provide financial analysis in corporations, financial reporting and accounting services for corporations and accounting firms, investment consultation to corporations and/or individuals, and other financial services. This professional definition allows us to develop curricula that deemphasizes the segregation of the finance and accounting departments in business schools and prepares graduates for a career in which they need a common set of skills to address the business issues which they will encounter.

The purpose of this paper is to begin discussion of curricula designed to meet the needs of the broadly defined financial professional. The proposed curriculum focuses on the competencies necessary to be an effective financial professional in today's diverse business environment and provide a solid foundation to enable the professional to pursue professional certifications such as Certified Financial Analyst, Certified Public Accountant, Certified Financial Manager, Certified Management Accountant, and a variety of others. Successful graduates who further their career by attaining professional certifications and fulfill their professional responsibilities will provide the greatest benefit to the financial profession and maintain the reputation of business schools. This paper is divided into discussions of: 1) the core competencies of financial professionals, 2) the need for change in accounting and finance curricula, and (3) a proposed undergraduate curriculum for financial professionals. 


\section{Core Competencies of Financial Professionals}

Significant research has focused on competencies necessary to be a successful accounting professional. In 1989, the large international firms were critical of accounting education in the preparation of students for nontechnical aspects of the profession (White Papers, 1989). Several major studies since then have focused on the development of the knowledge, skills, and education for accounting professionals in both corporate and public accounting. Research regarding educational process for typical finance majors has been more limited. However, two recent publications have addressed the knowledge, skills, and abilities necessary for financial executive leadership. These recent accounting and finance studies and their focus are summarized in Exhibit 1.

\section{Exhibit 1: Recent Core Competency Studies} Perspectives on Education:

Capabilities for Success in the Accounting Profession (White Papers, 2000) -- accounting practitioners encouraged greater development of the non-technical skills of students. Three sources of support for development of skills and knowledge for the successful accounting professional were individual talents, pre-entry education (typically undergraduate and graduate education), and continuing education and development.

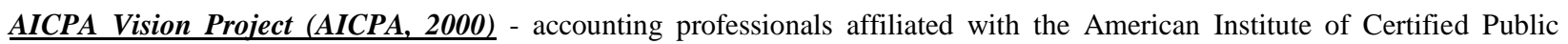
Accountants identified forces impacting the profession in the future and identified the core competencies of successful accountants in the future.

The Practice Analysis of Management Accounting - (IMA, 1996) - a survey of accounting professionals identified management accountants; critical work activities and the accounting knowledge, skills, and abilities (AKSAs) necessary to competently perform these activities.

Counting More, Counting Less - The 1999 Practice Analysis of Management Accounting (IMA, 1999) -- this survey of accounting professionals updated the 1996 study and expanded the AKSAs to include more team participation/leadership and strategic planning/process improvement.

CFO: - Architect of the Corporation's Future (PWC, 1999) - the PWC Team builds upon their CFO 2000 research program and discusses the changing demands on CFOs and personal qualities that will be increasingly important to CFOs in the future.

Leverage Competencies: The Key to Financial Leadership Success (Militello \& Swalberg, 2000) -- Militello and Swalberg attempt to articulate clearly the critical skills and competencies finance executives need to become effective business leaders of their organizations. They note that these competencies change as the professional advances in the organization.

Accounting Education: Charting the Course through a Perilous Future (Albrecht \& Sack, 2000) - a joint project of: the leading organizations in professional accounting and accounting education conducted by Albrecht and Sack emphasizing serious deficiencies in accounting education that could lead to its demise. They identify "six major categories of perceived problems: (1) course content and curriculum, (2) pedagogy, (3) skill development, (4) use of technology, (5) faculty development and reward structures, and (6) strategic planning and direction of accounting programs and departments."

Accounting and finance educational literature has previously been addressed separately; however, our broad view of the financial professional and scope of his/her responsibilities requires us to be all-inclusive in our consideration of their educational needs. The formal education of financial professionals is largely derived from knowledge in the traditional areas of accounting, finance, and economics. Practical responsibilities and competencies of financial professionals should be addressed by educators collaborating with finance and accounting practitioners. Therefore, we derive skills for the successful financial professional from research in the fields of finance and accounting.

Using research by the AICPA Vision Project (2000), the IMA Practice Analysis Projects $(1996,1999)$, the PricewaterhouseCoopers Financial \& Cost Management Team (PWC Team) (1999, and Militello and Schwalberg (2000), several of the most important competencies for the successful financial professional of the future are summarized in Exhibit 2. Rather than being all-inclusive, the competencies listed in this paper are those considered 
most important by financial professionals surveyed during the late 1990s and early 2000s. The relative importance of these competencies will vary with level of the job position in the organization and as changes occur in financial markets, corporations, and technology. Further scrutiny of Exhibit 2 supports that both technical and non-technical competencies are important to the success of the financial professional. The PWC Team (1999, p. 278-279) and Militello and Swalberg (2000, p. 2) reported that while most CFOs rate themselves competent in technical skills, many see opportunities for personal development regarding non-technical skills.

Exhibit 2: Overlapping Core Competencies for Financial Professionals

1. Interpersonal and leadership skills (including listening, communication skills, creativity, versatility, intuition drive, rigor);

2. Analytical/problem-solving skills and an understanding of the relationships between the balance sheet, income statement, and cash flow statements.

3. Technological proficiency;

4. $\quad$ Strategic and critical thinking skills;

5. A focus on the customer, client, and markets; and

6. A strong work ethic.

Militello and Schwalberg (2000) examined the relative importance of different competencies in their publication Leverage Competencies: The Key to Financial Leadership Success. The authors questioned whether financial executives really have the full range of competencies to be successful in their organizations. They define competency as "a personal trait or set of habits that are causally related to effective or superior job performance" (2000, p. 7). They categorize abilities of CFOs as foundation and leverage competencies. These competencies are described as follows:

Foundation competencies are professional, technical and control related -- these are the minimum competencies for all CFOs. In contrast, leverage competencies allow CFOs to build both the business (strategic thinking, innovation, managing business risk and change) and personal relationships (teamwork and coaching, inspiring leadership) (Mllitello \& Schwalberg, 2000, p. 1).

Knowledge and skill competencies (e.g., computer programming) are characteristics that can be readily developed through education and professional development. Self-concept competence (e.g., self-confidence) can be developed, but will require more time and effort. Motives (e.g., achievement orientation) and traits (e.g., emotional self-control) are core to the individual's personality and it may be more cost-effective to hire professionals with these capabilities, rather than attempting to develop them.

\section{Need for Change in Accounting and Finance Education}

The controversial study Accounting Education: Charting the Course through a Perilous Future (Albrecht \& Sack, 2000) was critical of accounting education and the relevancy of its curriculum in preparing students for their professional careers. The study identified "six major categories of perceived problems: (1) course content and curriculum, (2) pedagogy, (3) skill development, (4) use of technology, (5) faculty development and reward structures, and (6) strategic planning and direction of accounting programs and departments." Albrecht and Sack predict the demise of accounting education and the profession if rapid and significant changes are not implemented. Among the criticisms of the curriculum, several focused on the narrowness of course content and its irrelevancy to current accounting practices (Albrecht \& Sack, 2000).

Accounting courses are often overly focused on a series of technical rules and success with professional examinations, which previously have primarily tested technical knowledge and test-taking abilities. Accounting students are not exposed to a sufficiently broad business education with real-world examples. Introductory accounting provides students with a misperception of accountant's responsibilities by perpetuating the bookkeeping 
and rule-based orientation of the profession. The typical 150-hour accounting programs require students to take additional content-based courses, rather than learning other critical skills that will lead them to success.

This paper suggests that both accounting and finance educators need to reconsider their approach to education and incorporate the necessary technical and non-technical skills in the curriculum. Increasingly, financial professionals need a broader base of skills to succeed. Therefore, this paper will place an emphasis on developing a curriculum that will adequately address the relevant accounting and financial knowledge and skills that will enable students to succeed in providing a variety of financial responsibilities.

Companies are increasingly recognizing the commonality of the skills needed in the finance function. In a recent issue of Strategic Finance, nine of eleven positions that listed specific degrees preferred accounting and/or finance degrees (the other two positions listed only accounting degrees). Eight of these positions also expressed a preference for professional certification, typically either CPA and/or CMA. The positions listed in the Robert Half Finance \& Accounting Marketplace in the November, 2003 issue of Strategic Finance are as follows:

\begin{tabular}{ll}
\hline Position Title & \multicolumn{1}{c}{ Degree/Professional Certification Requirements } \\
\hline Cost Accountant & BS Degree in Accounting \\
Financial Analyst & BA/BS in Accounting, Finance, Economics, Business or Statistics; \\
& CPA, CMA, MBA, or ASAP preferred \\
Financial Analyst/Manager & Bachelor's Degree in Accounting or Finance; CPA, CMA preferred \\
Financial Controller & BS Degree in Accounting/Finance; CPA, CMA preferred \\
Controller & No Degree Specified \\
Financial Analyst & Degree in Accounting or Finance \\
Controller & No Degree Specified; CPA required \\
Controller & No Degree Specified; CPA preferred \\
Financial Analyst & BA in Accounting or Finance; MBA and/or CPA preferred \\
Staff Accountant & Accounting or related degree; CPA preferred \\
Senior Accountant & Accounting Degree \\
Finance Director & Accounting or Finance Degree \\
Financial Business Analyst & BA in Accounting or Finance; CMA preferred \\
Accounting Manager & Accounting or Finance Degree \\
\hline
\end{tabular}

Since the companies employ financial professionals with both accounting and finance degrees, we need to explore whether our accounting and finance curricula may need to be revised to accommodate these career tracks. A quick examination of accounting and finance curricula suggested to the authors that there is very little overlapping coursework in business schools for accounting and finance majors. This appears inconsistent with the hiring practices of our alumni by companies. Two groups of students requiring similar skills can benefit significantly from greater interaction. In a time of shrinking resources for universities, combining accounting and finance could make additional resources available to strengthen the combined accounting and finance programs. Given this concern, it seems logical to re-examine our curricula and their relevancy to today's business environment.. Attempts at a revised curriculum for the financial professional are discussed in the following sections.

\section{Undergraduate Curriculum for Financial Professionals}

We attempted to benchmark other undergraduate and graduate accounting and finance programs around the country to determine if new models existed that we could use to develop a new program. These attempts were largely unsuccessful due to a lack of innovation in curricula around the country. The recent study by Albrecht and Sack also noted practitioners' complaints that "we have just added 'more of the same"" when developing five-year accounting programs. This concern was largely supported as we attempted to identify innovative and relevant accounting and finance programs. 
The redesign of a combined undergraduate accounting and finance program should consider the skills necessary to be a successful financial professional. Advertisements for two job positions with different levels of experience from the November issue of Strategic Finance were as follows:

Financial Analyst: Health insurance company is seeking a Financial Analyst. Position will be responsible for both specific and general financial activities or functions, including assistance in the areas of profitability analysis, operating expense trends, business plan development, budgeting, cost accounting, and other areas relating to financial or managerial accounting and analysis. Individual will be involved in the direct support of operating department management by providing accurate and timely reports and analysis for influencing business decisions and achieving strategic goals. This position will require a detailed understanding of financial concepts and principles as applied to business operations. A CPA, CMA, MBA, or ASAP and health insurance experience are preferred. The qualified candidate will have a BA/BS in Accounting, Finance, Economics, Business or Statistics with $3+$ years of relevant and progressive experience.

Financial Controller: International manufacturing company has a great opportunity for a Plant Controller. Responsibilities include cash management, $\mathrm{A} / \mathrm{P}$ and $\mathrm{A} / \mathrm{R}$ management, financial planning, budget, audit, internal controls, cost measures and efficiencies. Position will have approximately four direct reports. A BS degree in Accounting/Finance with minimum of 6 years' experience is required, with 4+ years in a manufacturing environment. CPA or CMA preferred, but not required.

Both of these advertisements require either an accounting or finance degree and some experience. Obviously, the set of skills obtained from either degree are consistent with the expectations of the jobs, given the additional experience. Therefore, why not design a curriculum for a financial professional with more emphasis on as many of these skills as possible to give our graduates the greatest opportunity for advancement. To meet the demands of the marketplace for financial professionals, this redesigned curriculum would include both accounting and finance knowledge and skills. Initial attempts to design such curricula include similar proposals by French and Coppage (November, 2003) and by the Institute of Management Accountants [IMA's Curriculum Model (Russell \& Smith, December, 2003)]. The earlier curriculum presented by French at a national conference is a comprehensive curriculum for financial professionals and combines both accounting and finance curricula in academic institutions. The IMA Model proposes similar changes to accounting education, but does not specify changes to the course work in finance programs. Since the remainder of this paper suggests revision of both accounting and finance curricula proposed by French and Coppage, the remainder of this paper will build on this model curriculum.

Any attempt at redesigning the curriculum should include a consideration of core competencies and possible courses as presented in Exhibit 3. A variety of courses may often be used to accomplish the same objective, and those presented in Exhibit 3 are some illustrative examples of possible courses. Communication courses are essential for developing interpersonal and leadership skills, which should be practiced throughout the curriculum. Analytical and problem-solving skills are required throughout all accounting and finance courses. Technological proficiencies are developed by requirements for business applications using information systems throughout the program. Logic, ethical reasoning, and strategic thinking that promote critical thinking must be incorporated in specific courses and throughout the curriculum. A focus on customer issues is enhanced through a basic marketing course and exposure to classes incorporating professional marketing, client relationships, and customer profitability. Students must also understand that financial professional careers involve helping others make decisions, thus necessitating expansion of the definition of customers to anyone within and outside the organization who relies on our services. The final common core competency - a strong work ethic - must be emphasized throughout the students' entire college experience to install the high degree of commitment and rigor expected of financial professionals by our business customers and society as a whole.

Using these competencies, a proposed undergraduate curriculum may be designed, such as the example in Exhibit 4. The presentation of courses in Exhibit 4 is intended to be illustrative of courses that could be included in a complete program for the financial professional. The courses in Exhibit 4 are not intended to be all-inclusive. The program was developed in a way to combine both the accounting and finance curricula, while maintaining compatibility with the structure of courses and resources available at most Schools of Business in the United States. 
The proposed curriculum also fulfills the needs for general education and mission-driven requirements that are necessary to obtain AACSB accreditation.

Exhibit 3: Course Coverage of Core Competencies for Financial Professionals

\begin{tabular}{|ll|ll|}
\hline \multicolumn{2}{|c|}{ Core Competencies } & \multicolumn{1}{c|}{ Possible Courses or Other } \\
\hline 1. & $\begin{array}{l}\text { Interpersonal and leadership skills (including listening, } \\
\text { communication skills, creativity, versatility, intuition } \\
\text { drive, rigor). }\end{array}$ & $\bullet \begin{array}{l}\text { Communication Course(s) } \\
\text { Integrated Communication projects in other courses }\end{array}$ \\
\hline $\begin{array}{l}\text { 2. } \\
\text { of the relationships between the balance sheet, income } \\
\text { statement and cash flow statement. }\end{array}$ & $\begin{array}{l}\text { Financial Accounting Course(s) } \\
\text { Integrated analytic/problem-solving activities in other } \\
\text { courses }\end{array}$ \\
\hline 3. & Technological proficiency. & $\bullet \begin{array}{l}\text { Computer Course(s) } \\
\text { Integrate computer applications in other courses }\end{array}$ \\
\hline 4. & Strategic and critical thinking skills. & $\begin{array}{l}\text { Strategy Course(s)/Logic Course(s) } \\
\text { Integrate strategy and critical thinking activities in other } \\
\text { courses }\end{array}$ \\
\hline 5. A focus on the customer, client, and markets. & $\bullet \begin{array}{l}\text { Marketing Course(s) } \\
\text { Integrate marketing issues in other courses }\end{array}$ \\
\hline 6. & A strong work ethic. & $\begin{array}{l}\text { Maintain rigor and expect a high degree of responsibility } \\
\text { from the students in all courses }\end{array}$ \\
\hline
\end{tabular}

\section{Conclusion}

The undergraduate curriculum presented in this article is an attempt to redesign programs to meet the needs of a diverse group of students entering the financial profession. It was also an attempt to more effectively utilize resources of the institution and to offer a relevant financial program. We see the development of such a program as a way to bring additional relevancy into the accounting and finance curricula and to meet the requirements of professional financial certifications.

\section{Suggestions for Future Research}

Further studies are necessary to assure the continued success of higher education for aspiring financial professionals. Directions include defining more precisely what core competencies are necessary for accounting and finance professionals, including identifying the common competencies. Also, further discussion of the direction of change in accounting and finance higher education is necessary. Finally, if change is deemed necessary the most appropriate change(s) among numerous options should be explored. 


\section{Exhibit 4: Undergraduate Curriculum for Financial Professionals}

Undergraduate Curriculum for financial Professionals:

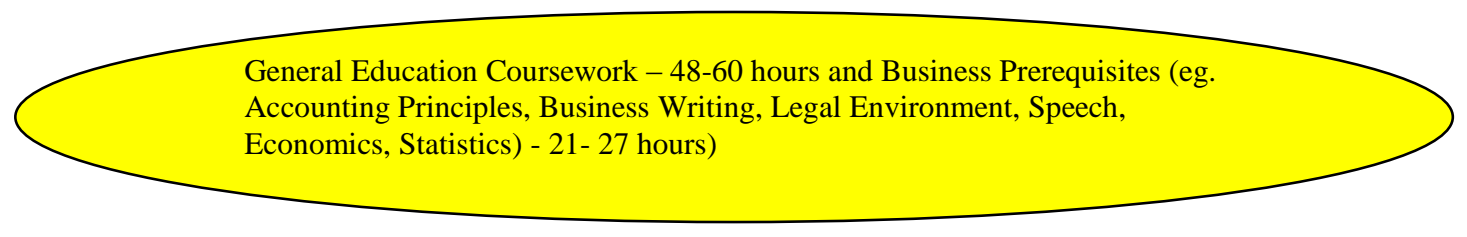

Core Business Classes (15 - 18 hours):
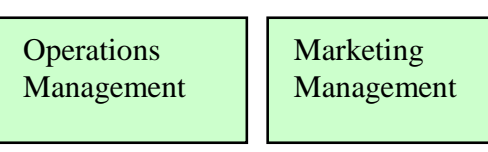

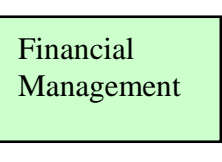

Business Management, Organizational Behavior

Major Courses for Financial Professionals (15-18 hours)

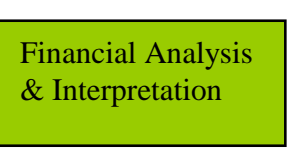

Financial Information Systems
Risk Management, Internal Controls, Auditing (Internal/External)
Information Systems for the Business Professional

Elective Courses (6-12 hours)

$\begin{array}{ll}\text { Intermediate Accounting } & \text { Money \& Banking } \\ \text { Mergers \& Acquisitions } & \text { International Accounting \& Finance } \\ \text { Individual Taxation } & \text { Derivatives (Acct \& Finance) } \\ \text { Auditing } & \text { Not-for-Profit Acct./Finance } \\ \text { Taxes and Business Decisions } & \end{array}$

$\underline{\text { Strategic Management (3 hours) }}$

Capstone Course - Integrates courses from all academic disciplines from the business school

\section{References}

1. Albrecht, W. S., and Sack, R. J., Accounting Education: Charting the Course through a Perilous Future. Accounting Education Series, Volume 16. Sarasota, FL: American Accounting Association, 2000.

2. Big 8 Accounting Firms (White Papers), Perspectives on Education: Capabilities for Success in the Accounting Profession, 1989.

3. French and Coppage, Presented at the 2003 Conference of the Academy of Business Disciplines in Fort Meyers, Florida, November, 2003.Indiana University Southeast (IUS), Bulletin 2002-2004. Master of Science in Strategic Finance. New Albany, IN: IUS, 2002. 
5. Institute of Management Accountants (IMA), The 1996 Practice Analysis of Management Accounting. Montvale, NJ: Institute of Management Accountants, 1996. Practice Analysis of Management Accounting. Montvale, NJ: Institute of Management Accountants, 1999.

6. Institute of Management Accountants (IMA), Counting More, Counting Less: The 1999 Militello, Jr., F.C., and Schwalberg, M.D., Leverage Competencies: The Key to Financial Leadership Success. Morristown, NJ: Financial Executives Research Foundation, Inc., 2000.

7. PricewaterhouseCoopers Financial \& Cost Management Team (PWC), CFO: Architect of the Corporation's Future. 2nd edition, 1999.

8. Russell, K.A., and Smith, C. S. Accounting Education's Role in Corporate Malfeasance: It's Time for a New Curriculum Strategic Finance, December, 2003, pp. 46-51.

Notes 